\title{
Effects of Vastus Lateralis Muscle Fascicle Length on Isokinetic Muscular Strength and Physical Fitness in Collegiate Athletes
}

\author{
Kwang-Jin Lee ${ }^{1}$, Ho-Seong Lee ${ }^{1^{*}}$ \\ ${ }^{1}$ Dankook University, Cheonan, Korea
}

\begin{abstract}
Received: April 28, 2020

Accepted: July 17, 2020

Published online: July 31, 2020

Keywords:

Collegiate Athletes

Isokinetic Muscular Strength

Physical Fitness

Vastus Lateralis Muscle Fascicle Length

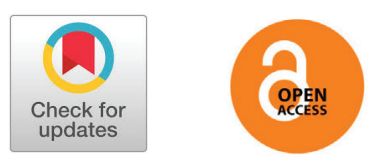

OBJECTIVES The purpose of this study was to examine the effects of vastus lateralis muscle fascicle length on isokinetic muscle strength and physical fitness in collegiate athletes.

METHODS 32 male collegiate athletes were classified into short fascicle length group ( $\mathrm{SFG}, \mathrm{n}=16$ ) and long fascicle length group ( $L F G, n=16$ ) by ultrasonic imaging. Both groups were tested for isokinetic muscular strength (peak torque, angle of peak torque and time to peak torque) and physical fitness ( $20 \mathrm{~m}$ sprint, T-drill, reaction time, side hop, square hop, figure of 8 hop, sergeant jump and Y-balance).

RESULTS LFG showed a positive effect on pennation angle $(p=.001)$, fascicle length $(p=.001)$, angle of peak torque at $180 \% \mathrm{sec}(p=.037)$, time to peak torque at $90 \% \mathrm{sec}$ and $180^{\circ} / \mathrm{sec}(p=.036 ; p=.039), 20 \mathrm{~m}$ sprint $(p=.016)$, T-drill ( $p=.005)$, side hop $(p=.001)$ and square hop $(p=.001)$, respectively compared to SFG. However, there was no difference between both groups of peak torque at $30 \% \mathrm{sec}, 90 \% \mathrm{sec}$ and $180 \% \mathrm{sec}$, angle of peak torque at $30 \% \mathrm{sec}$ and $90 \% \mathrm{sec}$, time to peak torque at $30 \% \mathrm{sec}$, reaction time, sergeant jump and Y-balance. CONCLUSIONS These results found that long fascicle length of vastus lateralis muscle have excellent isokinetic muscle strength and physical fitness in collegiate athletes.
\end{abstract}

(c) The Asian Society of Kinesiology and the Korean Academy of Kinesiology
서론

인체의 골격근은 뼈와 힘줄에 부착되어 근육의 수축 을 통해 움직임을 만드는 연부조직(soft tissue)으로 인 체의 기계적 움직임(mechanical movement)을 결정하 며, 근섬유의 배열(arrangement of muscle fiber)과 형 태에 따라 평행근(parallel muscles)과 깃털근(pennate muscles)으로 분류 된다[1]. 그 중에서 평행근은 근육 의 작용선(muscle's line of action)에 근 섬유가 평행 하게 배열된 형태이며, 팔꿈치 관절 등에 위치하여 관 절의 각도를 변화시키는데 적합한 구조이다[2]. 반면

*Correspondence: Ho-Seong Lee, Department of Kinesiologic Medical Science, Dankook University, 119, Dandae-ro, Cheonan-si, Korea; Tel: +82-41-550-3838; Fax: +82-41-559-7915; E-mail: hoseh28@dankook.ac.kr
에 깃털근은 근 섬유가 근육의 작용선에 사선으로 배 열된 형태이며, 근 섬유와 근육의 작용선이 이루는 각 도에 따라 근육이 수축하면서 힘을 발생시키고, 각도의 크기에 따라 근속(fascicle)의 수축 형태에 영향을 미칠 수 있다[3]. Watanabe et al. [1]은 근 섬유의 배열, 건 (tendon)의 부착 부위 및 근육의 작용선이 이루는 각도 를 깃각(pennation angle)이라고 하였으며, 깃각은 근 육의 두께(thickness)와 근속길이(fascicle length)의 구 조적 특성(muscle architecture)에 따라 그 크기가 달 라지는 것으로 보고하였다. 특히 깃털근은 중력을 대항 할 수 있도록 큰 단면적(cross sectional area)과 두께 를 가지고 있으며, 하지를 구성하고 있는 다수의 근육은 이러한 깃털근의 형태를 가지고 있다고 보고된다[2]. 
일반적으로 대퇴사두근을 구성하는 깃털근 중에 외 측광근(vastus lateralis muscle)은 근 단면적, 근육의 두께 및 깃각이 가장 많은 부분을 차지하며, 하지의 힘 발생(force generation)에 중요한 역할을 한다고 알려져 있다. 또한, 외측광근의 근속길이는 하지의 근수축 속도 (muscle contraction velocity)에 영향을 미치고, 그 길 이가 길수록 빠른 속도로 힘을 생성하는데 효과적이며, 근섬유에 직렬로 배열된 근절수의 증가에 따라 근수축 속도가 빨라진다[4]. 특히 Abe et al. [5]의 연구에 따 르면, 운동선수는 일반인에 비해 외측광근의 두께가 두 껍고, 깃각이 크며, 근속길이가 긴 구조적 특성을 가지고 있어 운동수행력이 우수한 것으로 보고되었으며, 그 중 에서 외측광근의 두께가 두껍고, 깃각이 큰 운동선수는 힘과 관련된 운동능력이 근육의 두께가 얇고 근속길이 가 긴 집단보다 우수한 것으로 보고되었다[6]. 앞서 언 급한 바와 같이, 운동선수의 외측광근의 두께와 깃각에 관한 형태학적 연구는 보고되고 있지만, 외측광근의 근 속길이에 따라 운동선수의 근력과 체력 등의 운동수행 력과의 관련성을 상세하게 평가하고 분석한 연구는 부 족한 실정이다. 아울러 외측광근의 근속길이는 하지의 수축 속도와 관련된 능력, 즉 속도와 밀접한 관련성이 있 다고 보고되었다[7]. 따라서 운동선수를 대상으로 외측 광근의 근속길이가 속도를 포함한 체력에 어떠한 영향 을 미치는가를 밝힐 필요가 있다고 생각한다.

한편, 등속성 근력(isokinetic muscular strength)은 최대근력, 최대근력의 발현각도 및 발현시간 등을 주요 변인으로 사용하고 있으며, 최대근력은 근육에서 발휘 할 수 있는 최대 힘이고, 최대근력의 발현각도는 최대근 력을 발현하기 위한 최적의 관절 각도이며, 최대근력의 발현시간은 최대근력이 발생되는 시간을 의미한다[8]. 즉 최대근력은 근육의 힘을, 최대근력의 발현각도는 힘 을 낼 수 있는 관절가동범위를, 그리고 최대근력의 발현 시간은 근수축의 속도를 나타내는 것이며, 이들은 개인 의 수준과 종목의 특성 및 훈련 방법의 차이에 따라 다 양하게 나타난다고 할 수 있다[9]. 특히 Alegre et al. [10]은 근수축의 속도는 외측광근의 근속길이와 밀접 한 관련성이 있으며, 근속길이는 종목별 및 단일종목의 운동선수 수준에 따라 다르게 나타났다고 보고하였다 [5]. 따라서 근속길이는 운동선수 개인의 근력과 체력의 지표이며, 종목과 상관없이 다양한 관점에서 이러한 관 련성을 파악하는 것은 스포츠 현장에서 맞춤형 훈련 방
법을 개발하고 개선하는데 도움이 될 것으로 생각된다. 이에 이 연구에서는 대학 운동선수를 대상으로 외측광 근의 근속길이가 등속성 근력 및 체력에 차이를 나타낼 것이라는 가설을 검증하는데 그 목적이 있다.

\section{연구방법}

\section{연구 대상}

연구대상은 C지역 소재 대학에 재학 중인 운동 경 력이 7년 이상인 남자 대학 운동선수 32 명(검도 7명, 레슬링 8명, 축구 8명, 정구 7명)이다. 집단은 초음파 영상을 통해 외측광근의 근속길이를 측정한 후 중위값 을 기준으로 하위 $50 \%$ 는 근속길이가 짧은 집단(short fascicle length group; SFG, n=16)과 상위 $50 \%$ 는 근 속길이가 긴 집단(long fascicle length group, LFG, $\mathrm{n}=16)$ 으로 분류하였다[11,12]. 이 연구에서는 표본 수 를 검정하기 위하여 $\mathrm{G}$-power 3.0을 사용하여 유의수 준 .05, 효과 크기 .05, 검정력 .95을 설정한 결과, 각 집단에 16 명의 표본 수가 요구되었다. 모든 대상자에게 연구의 목적과 내용을 충분히 설명하고 참가 동의서에 서명을 받았다. 연구대상의 신체적 특성은 〈Table 1> 에 제시한 바와 같다.

\begin{tabular}{lll}
\multicolumn{2}{l}{ Table 1. Characteristic subjects } \\
\hline Variables & SFG $(\mathrm{n}=16)$ & LFG $(\mathrm{n}=16)$ \\
\hline Age (years) & $20.6 \pm 1.18$ & $21.0 \pm 1.06$ \\
Height $(\mathrm{cm})$ & $173.7 \pm 4.44$ & $175.3 \pm 3.85$ \\
Weight $(\mathrm{kg})$ & $76.8 \pm 7.97$ & $72.8 \pm 5.69$ \\
Body fat $(\%)$ & $16.3 \pm 5.20$ & $13.8 \pm 3.45$ \\
BMI (kg/m²) & $22.1 \pm 2.16$ & $21.5 \pm 1.92$ \\
Career (years) & $10.8 \pm 1.74$ & $9.6 \pm 2.61$ \\
\hline
\end{tabular}

Values are mean $\pm S D, S F G$ : short fascicle length, LFG: long fascicle length

\section{측정 절차}

이 연구에 참여한 모든 대상자는 외측광근의 근속 길이, 등속성 근력 및 체력을 3 일 동안 걸쳐서 측정하 였다. 1일 차에는 초음파 영상장치(Arietta 60, Hitachi Medical, Japan)를 이용하여 외측광근의 두께와 깃각을 측정하였으며, 삼각형 빗변을 구하는 공식을 통해 외측 광근의 근속길이를 구하였다. 1 주일의 휴식을 취한 후 에 2 일 차에는 최대근력, 최대근력의 발현각도 및 최대 
근력의 발현시간을 $30 \% \mathrm{sec}, 90 \% \mathrm{sec}$ 및 $180 \% \mathrm{sec}$ 에서 각각 측정하였다. 재차 1 주일의 휴식을 취한 후에 3 일 차에는 $20 \mathrm{~m}$ 전력질주, $\mathrm{T}$ 검사, 반응시간, 외발뛰기, 수 직점프 및 $\mathrm{Y}-$ 밸런스를 각각 측정하였다. 민첩성과 스 피드는 $20 \mathrm{~m}$ 전력질주와 $\mathrm{T}$ 검사를 이용하여 평가하였 으며, 순발력은 수직점프, 외발뛰기를 이용해 평가하였 다. 동적균형은 $\mathrm{Y}$-밸런스를 이용해 평가하였으며, 반응 시간은 종합체력측정기를 이용해 평가하였다.

\section{측정 항목 및 방법}

\section{1) 외측광근의 근속길이}

외측광근의 근속길이는 근·골격계 측정용 초음파 를 통해 초음파 전용 탐촉자와 $\mathrm{B}$-모드 스캔 방법을 사 용하여 외측광근의 두께와 깃각을 각각 측정한 후에 두께와 깃각의 값을 직각 삼각형 빗변 공식\{fascicle length $(\mathrm{cm})=$ muscle thickness $(\mathrm{cm}) / \sin$ (pennation angle $\left.{ }^{\circ}\right\}$ 을 이용하여 구하였다 $[6,10]$. 외측광근의 측정 위치는 기시점과 정지점의 $50 \%$ 지점이며, 인체계측용 전용 줄자를 사용하여 피부 표면에 그 위치를 표시하였 다. 피험자는 초음파 측정 전용 침대 위에 바로 누운 자 세를 취하게 하였으며, 초음파 전용 탐촉자를 이용하여 피부에 표시된 지점을 측정하였다. <Figure 1>에 제시 한 바와 같이, 외측광근의 두께는 얇은 건막과 깊은 건 막 사이의 거리를 측정하였으며, 깃각은 깊은 건막과 근 속이 이루는 각도를 측정하였다.

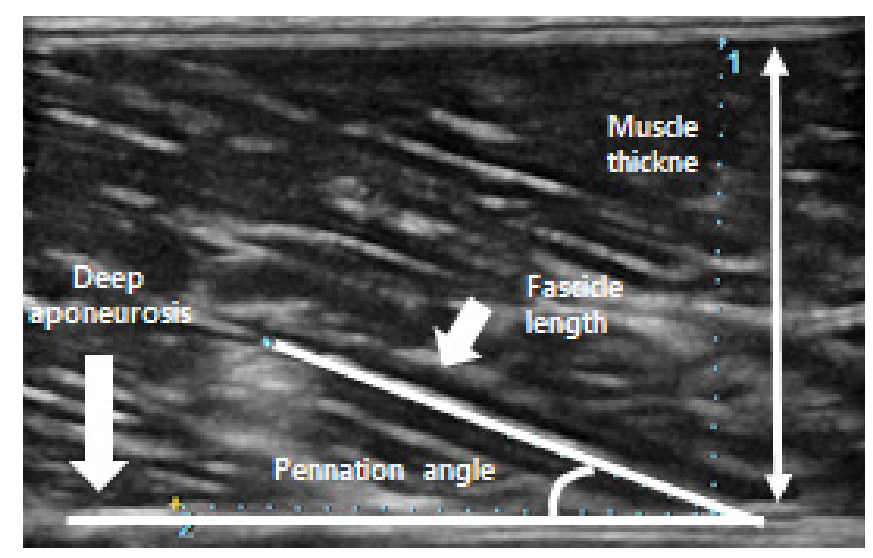

Figure 1. Ultrasound picture of vastus lateralis muscle.

\section{2) 등속성 근력}

등속성 근력은 등속성 장비(Biodex system 3, Biodex Medical Systems, USA)를 사용하여 $30 \%$ sec,
$90 \% \mathrm{sec}$ 및 $180 \% \mathrm{sec}$ 에서 각각 측정하였다. 최대근력, 최대근력의 발현각도 및 최대근력의 발현시간은 등속 성 장비로 측정할 수 있는 등속성 근력의 하위변인으로 $30 \% \mathrm{sec}, 90 \% \mathrm{sec}$ 및 $180 \% \mathrm{sec}$ 의 프로토콜에서 각각 5 회씩 측정하였다. 피험자는 등속성 근력을 측정하기 전 10 분간의 준비운동을 실시하였으며, 피험자는 등속성 근력을 측정하기 위해 의자에 앉게 한 후 고정 끈으로 가슴과 허리 부위 및 대퇴부를 고정하였으며, 무릎관절 의 외측상과와 동력계 회전축이 평행하도록 의자의 위 치를 조정하였다. 등속성 근력의 측정 중에는 피험자가 측정에 집중할 수 있도록 측정 의자 옆에 있는 손잡이를 붙잡도록 하였다. 피험자는 등속성 측정 장비의 사용방 법에 익숙해지도록 무릎의 신전과 굴곡을 실시한 후에 주측발의 등속성 근력을 측정하였다[13].

\section{3) 체력}

체력은 $20 \mathrm{~m}$ 전력질주, $\mathrm{T}$ 검사, 반응시간, 외발뛰기 (좌·우, 사각형, 8자), 수직점프 및 $\mathrm{Y}$-밸런스를 각각 측 정하였다. $20 \mathrm{~m}$ 전력질주는 구간 스피드 측정기(SR500 , Seedtech, Korea)를 이용하여 측정하였다. T 검 사는 구간 스피드 측정기(SR-500, Seedtech, Korea) 를 이용하여 측정하였다. 반응시간과 수직점프는 종합 체력 측정기(BS-FS, Inbody, Korea)를 이용하여 측정 하였다. 반응시간은 측정자가 매트 위에 두 발로 선후 에 종합 체력 측정기의 기계음 신호가 주어질 때 두 발 이 매트에 떨어지는 시간을 측정하였으며, 수직점프는 무릎을 $90^{\circ}$ 구부린 상태에서 제자리 점프를 실시하였 고, 두 발이 매트에서 떨어진 높이를 측정하였다. 외발 뛰기는 Docherty et al. [14] 의 검사방법을 사용하였 으며, 좌·우 사각형 및 8자 외발뛰기를 각각 측정하였 다. Y-밸런스는 Plisky et al. [15]의 측정방법을 사용하 였으며, 3 가지 방향에서 측정된 기록의 합을 정규화 공 식\{(anterior+ posterior medial+ posterior lateral)/ $(3 \times$ leg length $) \times 100)\}$ 을 이용하여 구하였다.

\section{자료 처리}

이 연구의 자료 처리는 SPSS 20.0(SPSS Inc., Chicago, IL, USA)을 이용하여 기술 통계치 (Means $\pm \mathrm{SD}$ )를 산출하였으며, Kolmogorov-Smirnov 검정 방법을 사용하여 모든 변인의 정규 분포를 확인하 였다 $(\mathrm{p}>.05)$. 집단 간의 차이를 각각 비교 분석하기 위 
하여 독립 표본 $\mathrm{t}$-검정(Independent samples T-Test) 을 실시하였으며, 모든 통계적 유의 수준은 $a=.05$ 로 설 정하였다.

\section{결과}

\section{외측광근의 구조적 특성}

외측광근의 구조적 특성은 <Figure 2>에 제시한 바 와 같다. 먼저, 외측광근의 깃각은 $\mathrm{LFG}$ 와 비교해서 $\mathrm{SFG}$ 에서 유의하게 높은 것으로 나타났으며 $(\mathrm{p}=.001)$, 외측광 근의 근속길이는 $\mathrm{SFG}$ 와 비교해서 $\mathrm{LFG}$ 에서 유의하게 긴 것으로 나타났다 $(\mathrm{p}=.001)$. 그러나 외측광근의 두께는 집 단 간에 통계학적으로 유의한 차이가 나타나지 않았다.
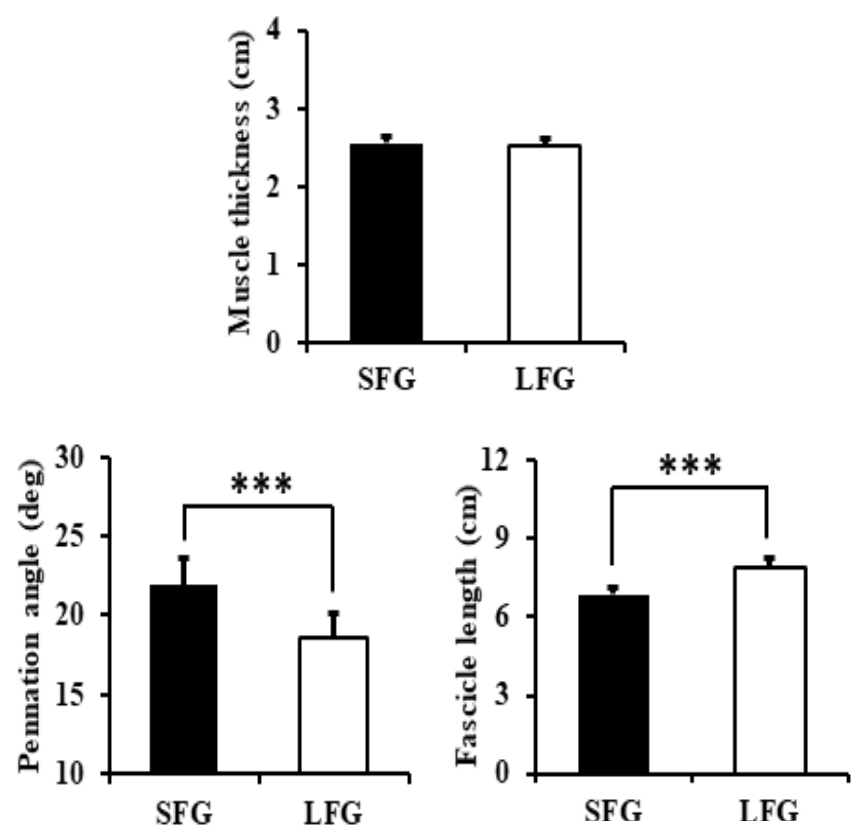

Figure 2. Changes in vastus lateralis muscle fascicle length in SFG and LFG. ${ }^{* * *} p<.001$, SFG: short fascicle length group, LFG: long fascicle length group.

\section{등속성 근력}

\section{1) 최대근력}

최대근력은 <Figure 3>에 제시한 바와 같다. $30 \%$ $\mathrm{sec}, 90 \% \mathrm{sec}$ 및 $180 \% \mathrm{sec}$ 에서 최대근력은 집단 간에 통계학적으로 유의한 차이가 나타나지 않았다.

\section{2) 최대근력의 발현각도}

최대근력의 발현각도는 <Figure 4>에 제시한 바 와 같다. $180 \% \mathrm{sec}$ 에서 최대근력의 발현각도는 $\mathrm{SFG}$ 와 비교해서 $\mathrm{LFG}$ 에서 유의하게 높은 것으로 나타났다
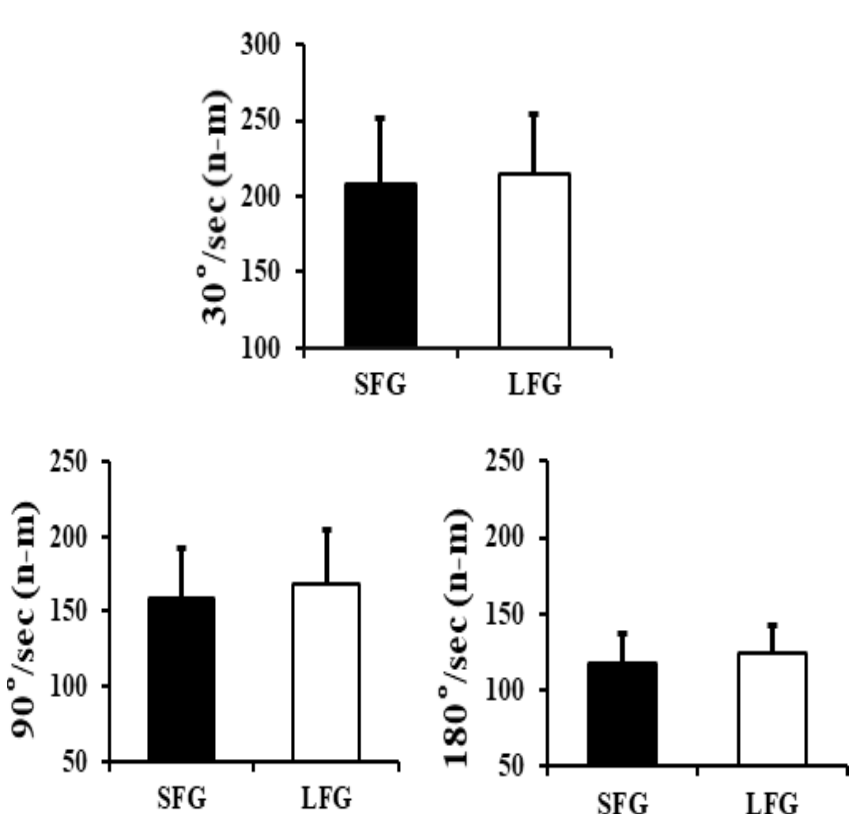

Figure 3. Changes in peak torque in SFG and LFG. SFG: short fascicle length group, LFG: long fascicle length group.
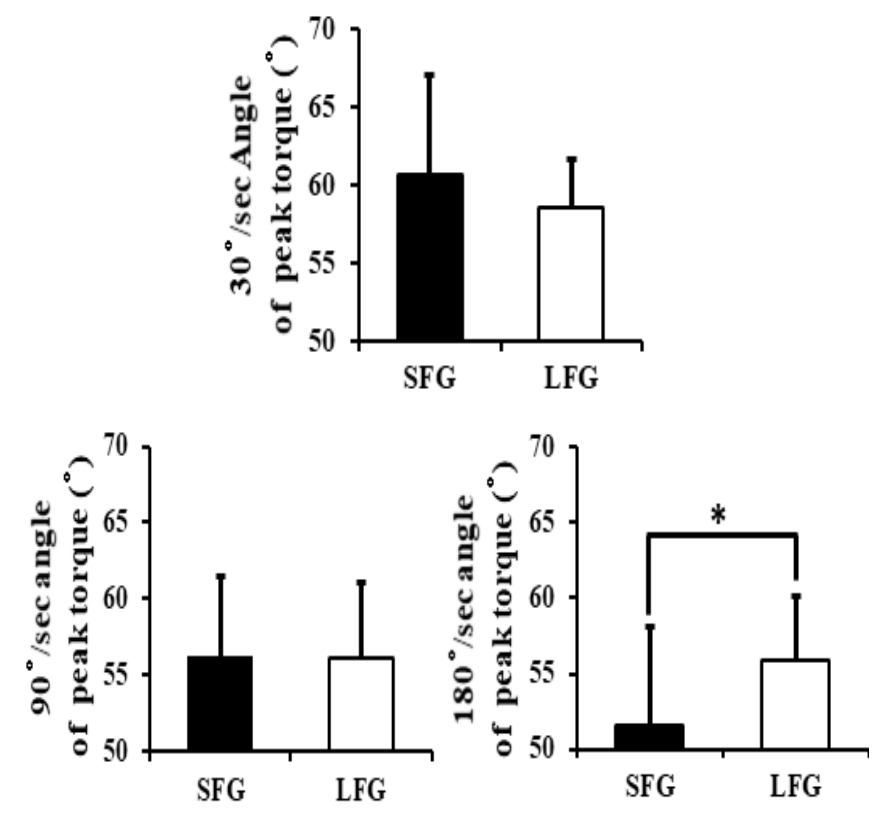

Figure 4. Changes in angle of peak torque in SFG and LFG. ${ }^{*} p<.05, \mathrm{SFG}$ : short fascicle length group, LFG: long fascicle length group.

( $\mathrm{p}=.037)$. 그러나 $30 \% \mathrm{sec}$ 및 $90 \% \mathrm{sec}$ 에서 최대근력의 발현각도는 집단 간에 통계학적으로 유의한 차이가 나 타나지 않았다.

3) 최대근력의 발현시간

최대근력의 발현시간는 <Figure 5 >에 제시한 바와 

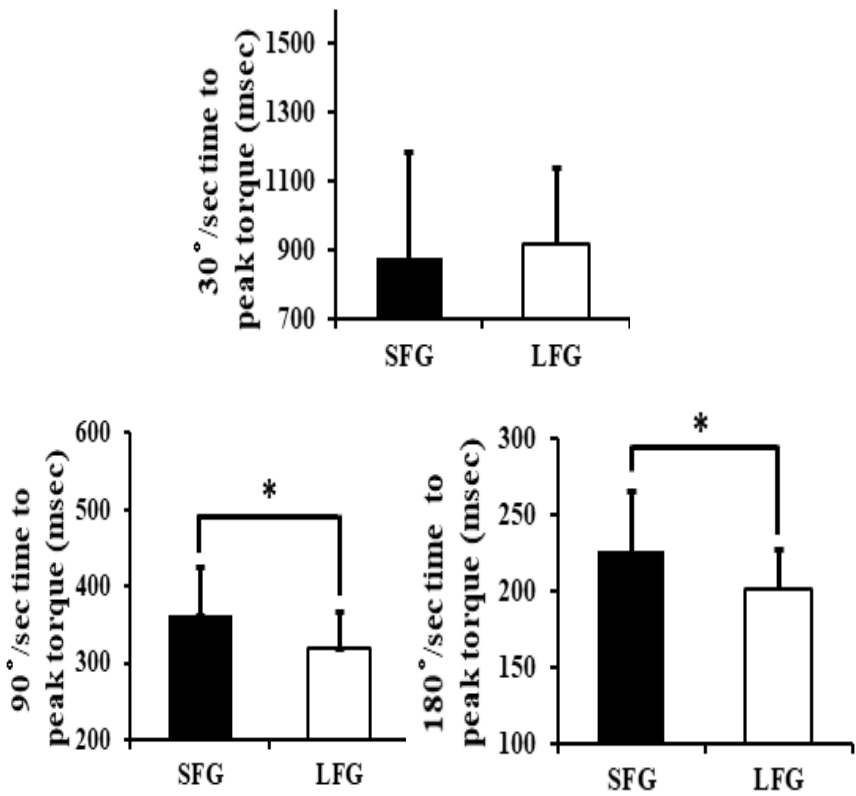

Figure 5. Changes in time of peak torque in SFG and LFG. ${ }^{*} p<.05$, SFG: short fascicle length group, LFG: long fascicle length group.

같다. $90 \% \mathrm{sec}$ 및 $180 \% \mathrm{sec}$ 에서 최대근력의 발현시간 은 $\mathrm{SFG}$ 와 비교해서 $\mathrm{LFG}$ 에서 유의하게 빠른 것으로 나 타났다 $(\mathrm{p}=.036, \mathrm{p}=.039)$. 그러나 $30 \% \mathrm{sec}$ 의 최대근력 의 발현시간은 집단 간에 통계학적으로 유의한 차이가 나타나지 않았다.

\section{체력}

체력은 <Figure 6>에 제시한 바와 같다. $20 \mathrm{~m}$ 전력질 주 $(\mathrm{p}=.016), \mathrm{T}$ 검사 $(\mathrm{p}=.005)$, 좌·우 외발뛰기 $(\mathrm{p}=.001)$ 및 사각형 외발뛰기 $(\mathrm{p}=.001)$ 는 SFG와 비교해서 LFG에 서 유의하게 긍정적인 결과를 보였다. 그러나 반응시간, 8자 외발뛰기, 수직점프 및 $\mathrm{Y}$-밸런스는 집단 간에 통계 학적으로 유의한 차이가 나타나지 않았다.

논의

이 연구에서는 외측광근의 근속길이가 대학운동선수 의 등속성 근력 및 체력에 미치는 영향을 분석한 결과, $180 \% \mathrm{sec}$ 에서 최대근력의 발현각도, $90 \% \mathrm{sec}$ 및 $180 \%$ $\mathrm{sec}$ 에서 최대근력의 발현시간은 외측광근의 근속길이 가 짧은 집단 $(\mathrm{SFG})$ 과 비교해서 외측광근 근속길이가 긴 집단(LFG)에서 긍정적인 결과를 보였으며, $20 \mathrm{~m}$ 전력질 주, $\mathrm{T}$ 검사, 좌·우 외발뛰기 및 사각형 외발뛰기는 $\mathrm{SFG}$
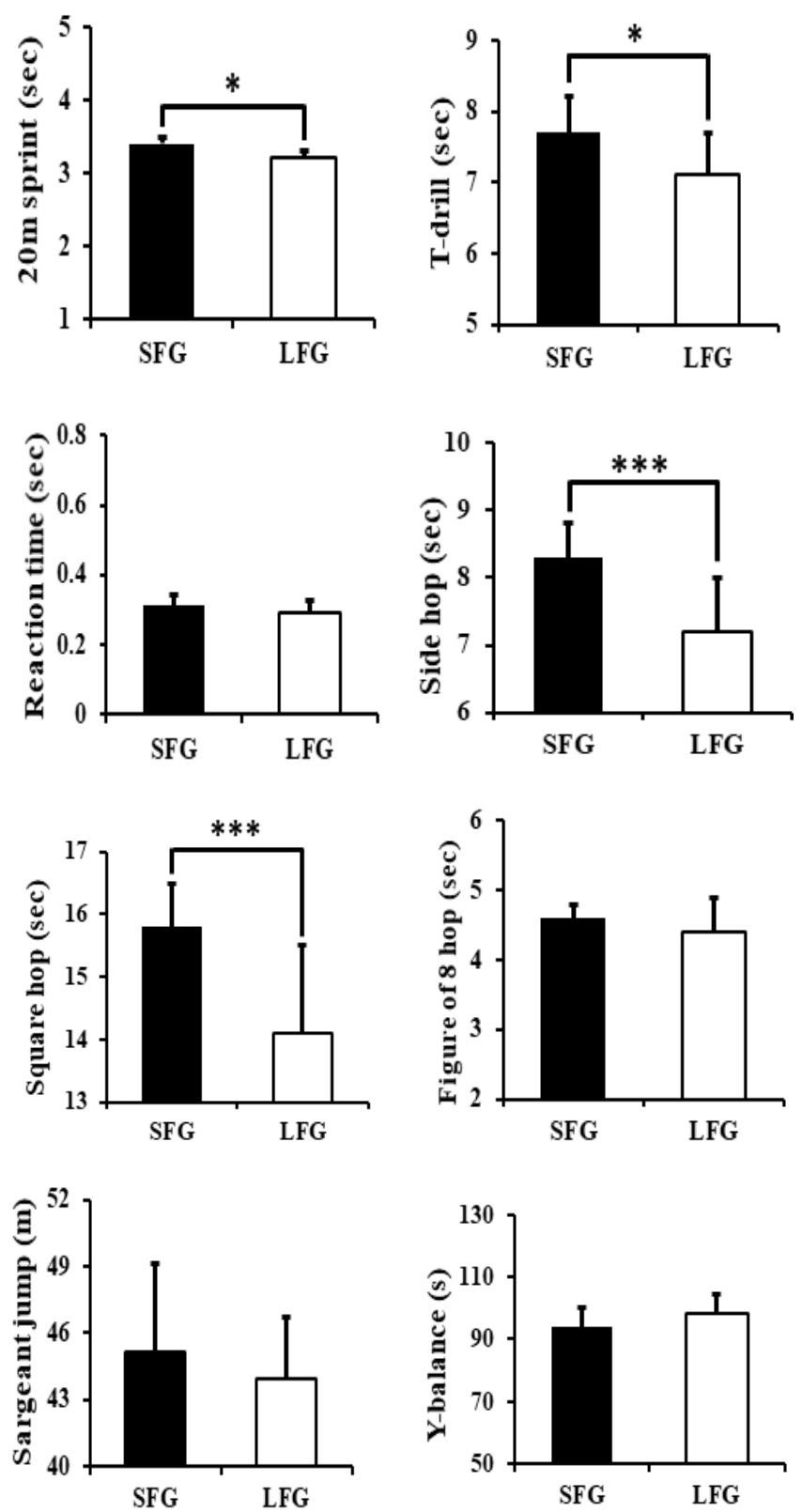

Figure 6. Changes in physical fitness in SFG and LFG. ${ }^{*} \mathrm{p}<.05,{ }^{* * *} \mathrm{p}<.001$, SFG: short fascicle length group, LFG: long fascicle length group.

와 비교해서 LFG에서 긍정적인 결과를 보였다. 따라서 외측광근의 근속길이가 긴 대학운동선수는 등속성 근력 및 체력이 우수 하다는 사실을 확인 하였으며, 특히 LFG 에 검도(3명)와 레슬링(2명) 선수에 비해 축구(5명)와 정구(6명) 선수의 비율이 높은 것으로 나타나 종목과 관 련된 특정 체력 요인이 영향을 주었을 것이라 생각한다.

이 연구에서 외측광근의 깃각은 $\mathrm{LFG}$ 와 비교해서 $\mathrm{SFG}$ 에서 유의하게 높은 것으로 나타났으며, 근속길이 
는 SFG와 비교해서 $\mathrm{LFG}$ 에서 유의하게 긴 것으로 나 타났다. 선행연구에 의하면, 운동선수의 외측광근의 근 속길이는 근육의 두께보다 근육의 깃각과 밀접한 관련 성이 있는 것으로 보고되고 있으며[6], 근속길이는 근 육 수축 시 생화학적 반응 $(\mathrm{ATP}-\mathrm{PC})$ 에 영향을 받아 근 육의 수축 속도를 결정하는데 중요한 요인이라고 하였 다[16]. Kumagai et al. [17]은 우수 운동선수는 외측 광근의 깃각이 작고 근속길이가 긴 것으로 나타났으며, 외측광근의 근속길이가 길수록 $100 \mathrm{~m}$ 기록이 우수하다 고 보고하였다[5]. 특히 Blazevich et al. [18]은 외측 광근의 근속길이는 근육의 수축 속도와 운동능력을 결 정하는데 중요한 영향을 미치며, 운동선수의 훈련 형태 와 방법에 따라 외측광근의 근속길이에 영향을 미친다 고 하였다. 따라서 이 연구에서 외측광근의 근속길이가 긴 대학운동선수는 외측광근의 깃각이 작고 근속길이가 긴 것으로 나타난 것은 운동선수의 종목의 특성과 훈련 형태가 영향을 미쳤을 것이라 판단된다.

이 연구에서 $180^{\circ} / \mathrm{sec}$ 에서 최대근력의 발현각도는 $\mathrm{SFG}$ 와 비교해서 $\mathrm{LFG}$ 에서 유의하게 높은 것으로 나타 났다. 최대근력의 발현각도는 운동선수가 경기나 훈련 중에 요구되는 동작을 빠르고 정확하게 전개해 나가는 데 있어 필요한 요소이며, 근섬유의 분포 및 근육의 구 조적 특성과 밀접한 관련성이 있다[19]. 또한 최대근력 의 발현각도는 관절운동의 초기에 일반인 $\left(40^{\circ} \sim 45^{\circ}\right)$ 과 비교해서 운동선수에 게 $\left(50^{\circ} \sim 60^{\circ}\right)$ 높게 나타났으며 [20], $180 \% \mathrm{sec}$ 에서 최대근력의 발현각도는 운동초기에 청소 년 국가대표 배구선수와 비교해서 국가대표 배구선수에 서 높게 나타났다[19]. 아울러 $180 \%$ sec에서 최대근력 의 발현각도는 일반 스키선수와 비교해서 우수 스키선 수에서 높게 나타났으며 [21], Brughelli et al. [22]은 최대근력의 발현각도는 근속길이가 짧은 운동선수에 비 해 근속길이가 긴 운동선수가 높게 나타나는 것으로 보 고하면서, 운동선수의 체력 요인과 근속길이의 구조적 특성에 따라 변화한다고 추론하였다. 특히 이 연구에서 $\mathrm{LFG}$ 에서 최대근력의 발현 각도가 $\mathrm{SFG}$ 에 비해 운동 초 기에 크게 나타난 것은 외측광근의 근속길이가 최대근 력의 발현각도에 긍정적인 영향을 미쳤기 때문인 것으 로 생각한다.

이 연구에서 $90 \% \mathrm{sec}$ 및 $180 \% \mathrm{sec}$ 에서 최대근력의 발현시간은 SFG와 비교해서 $\mathrm{LFG}$ 에서 유의하게 빠른 것으로 나타났다. Singh et al. [23]은 최대근력의 발현
시간은 훈련의 정도나 근육의 기능을 평가하는데 중요 하다고 하였으며, Blazevich \& Jenkins[24]는 훈련 방 법에 따른 최대근력의 발현시간을 분석한 결과, 최대근 력의 발현시간은 전력 질주 훈련을 받지 않은 집단과 비 교해서 전력 질주 훈련 집단에서 긍정적인 결과를 보였 다고 보고하면서, 훈련에 따른 근육의 생리학적 변화에 대한 중요성을 시사하였다. 특히 Blazevich et al. [18] 은 다양한 종목 선수(축구, 럭비, 넷볼)를 혼합하여 3 집 단으로 분류한 후에 집단 별로 각각 다른 형태의 훈련 을 5 주간 실시하여 외측광근 근속길이의 변화를 비교 한 결과, 운동선수의 외측광근의 근속길이는 다른 운동 형태와 비교해서 Sprint/jump 훈련에서 보다 긍정적인 영향을 준다고 보고하면서, 힘과 속도에 따른 훈련의 특 성이 외측광근의 구조적 특성에 변화를 가져왔기 때문 이라고 주장하였다. 즉, 빠른 속도의 훈련과 운동 형태 에 따른 외측광근 근속길이의 변화는 근육의 힘선과 평 행하게 수축되는 근섬유의 증가와 근육 수축 속도를 향 상시켜 최대근력의 발현시간을 단축시켰다고 추론하였 다. 따라서 이 연구에서 $\mathrm{LFG}$ 에서 최대근력의 발현시간 이 빠르게 나타난 것은 외측광근의 근속길이가 최대근 력의 발현시간에 영향을 미쳤다는 사실을 확인시켜준 결과라고 생각한다.

한편, 이 연구에서 $20 \mathrm{~m}$ 전력질주 및 $\mathrm{T}$ 검사는 $\mathrm{SFG}$ 와 비교해서 $\mathrm{LFG}$ 에서 유의하게 높은 것으로 나타났다. 근속길이는 근절(sarcomere)의 길이와 수에 따라 달라 지며, 외측광근의 근속길이가 길수록 근수축 속도가 빨 라져서 전력 질주 능력에 영향을 미친다고 하였다[25]. Methenitis et al. [26]은 훈련 기간에 따른 외측광근 의 근속길이의 변화를 분석한 결과, 훈련 기간이 길수록 외측광근의 근속길이에 긍정적인 영향을 미친다고 하였 으며, 저 중량의 고속도 훈련은 외측광근의 근속길이의 변화를 초래하여 전력 질주 능력이 향상된다고 하였다 [27]. 특히 Abe et al. [5]은 우수한 운동선수일수록 외 측광근의 근속길이가 길고 전력 질주의 능력이 우수하다 고 보고하면서, 다양한 훈련 방법과 기간은 운동선수의 외측광근 근속길이의 차이를 발생시킬 가능성이 있다고 추론하였다. 또한 민첩성(Agility)은 전력 질주와 다른 체력요소이지만, 스프린트와 밀접한 상관성이 있으며, 전력 질주와 마찬가지로 짧은 구간을 빠른 속도로 움직 이는 능력이 필수적이다고 보고하였다[28]. Luteberget [29]의 연구에 따르면, 핸드볼 선수의 외측광근의 근속 
길이와 민첩성은 높은 상관관계가 있으며, 외측광근의 근속길이가 길수록 민첩성이 향상되었다고 보고하였다. 이 연구에서 $20 \mathrm{~m}$ 전력질주와 $\mathrm{T}$ 검사가 $\mathrm{SFG}$ 와 비교해 서 $\mathrm{LFG}$ 에서 우수하게 나타난 것도 외측광근의 근속길 이가 $20 \mathrm{~m}$ 전력질주와 민첩성의 $\mathrm{T}$ 검사에 긍정적인 영 향을 미쳤기 때문이라고 생각한다.

이 연구에서 좌·우 외발뛰기와 사각형 외발뛰기는 $\mathrm{SFG}$ 와 비교해서 $\mathrm{LFG}$ 에서 유의하게 높은 것으로 나타 났다. 외발뛰기는 스포츠에서 발생하는 커팅, 회전 및 점프 동작을 수행하는데 필요한 하지의 근력, 순발력 및 균형 등의 체력을 측정하는 방법으로[30], Paterno et al. [31]은 운동 특이적 수행력(sports-specific performance)을 평가하는데 효과적이라고 하였다. 선 행연구에 의하면, 외발뛰기는 일반 선수와 비교해서 우 수 선수에서 유의하게 높게 나타났으며 [32], Brumitt et al. [33]은 외발뛰기는 운동선수의 리그 수준, 선수 포지션 및 수준이 우수할수록 높게 나타났다고 보고하 였다. 특히 외발뛰기는 높은 근수축 속도가 요구됨에 따 라 전력 질주와 민첩성 등의 체력 요소와 밀접한 관련성 이 있다고 보고하였다[34]. 따라서 이 연구에서 SFG와 비교해서 LFG에서 좌 우 외발뛰기와 사각형 외발뛰기 가 긍정적인 결과를 나타낸 것은 근속길이가 긴 운동선 수의 근력수준이 외발뛰기에 긍정적인 영향을 미쳤기 때문이라고 생각된다.

\section{결론}

이 연구에서 외측광근의 근속길이가 대학운동선수 의 등속성 근력과 체력에 미치는 영향을 분석한 결과, $180 \% \mathrm{sec}$ 에서 최대근력의 발현각도, $90 \% \mathrm{sec}$ 및 $180 \%$ $\mathrm{sec}$ 에서 최대근력의 발현시간, $20 \mathrm{~m}$ 전력질주, $\mathrm{T}$ 검사, 좌·우 외발뛰기 및 사각형 외발뛰기는 SFG와 비교해서 LFG에서 유의하게 높게 나타났다. 따라서 이 연구에서 외측광근의 근속길이가 긴 대학운동선수는 등속성 근력 및 체력이 우수하다는 사실을 확인하였다. 향후에는 외 측광근의 근속길이뿐만 아니라 하지 근육의 구조적 특 성과 운동 및 훈련 개입에 따른 외측광근의 근속길이의 변화가 근력 및 체력 등의 운동수행력에 미치는 영향을 보다 상세히 검토할 필요가 있다고 생각한다.

\section{Acknowledgments}

이 연구는 이광진의 박사학위(2019)을 수정 보완한 것임

\section{References}

1. Watanabe K, Otsuki S, Hisa T, Nagaoka M. Functional difference between the proximal and distal compartments of the semitendinosus muscle. J Phys Ther Sci. 2016; 28(5):1511-1517.

2. Azizi E, Roberts TJ. Geared up to stretch: pennate muscle behavior during active lengthening. J Exp Biol. 2014; 217(3):376-381.

3. Meyer DC, Gerber C, Farshad M. Negative muscle pennation angle as a sign of massive musculotendinous retraction after tendon tear: paradoxical function of the vastus lateralis muscle. KSSTA. 2011; 19(9):1536.

4. Blazevich AJ, Gill ND, Zhou S. Intra-and intermuscular variation in human quadriceps femoris architecture assessed in vivo. J Anat. 2006; 209(3):289-310.

5. Abe T, Fukashiro S, Harada Y, Kawamoto K. Relationship between sprint performance and muscle fascicle length in female sprinters. J Physiol Anthropol Appl Human Sci. 2001; 20(2):141-147.

6. Secomb J L, Nimphius S, Farley OR, Lundgren LE, Tran TT, Sheppard JM. Relationships between lower-body muscle structure and, lower-body strength, explosiveness and eccentric leg stiffness in adolescent athletes. J Sports Sci Med. 2015; 14(4):691.

7. Abe T, Kumagai K, Brechue WF. Fascicle length of leg muscles is greater in sprinters than distance runners. Med Sci Sports Exerc. 2000; 32(6):1125-1129.

8. Bernard PL, Amato M, Degache F, et al. Reproducibility of the time to peak torque and the joint angle at peak torque on knee of young sportsmen on the isokinetic dynamometer. Ann Phys Rehabil Med. 2012; 55(4):241251.

9. Cronin JB, Hansen KT. Strength and power predictors of sports speed. J Strength Cond Res. 2005; 19(2):349-357.

10. Alegre LM, Jiménez F, Gonzalo-Orden JM, Martín-Acero 
R, Aguado X. Effects of dynamic resistance training on fascicle length and isometric strength. J Sports Sci. 2006; 24(05):501-508.

11. Jin JD, Lee HS. Effects of Vastus Lateralis Muscle Fascicle Length on Isokinetic Muscle Strength and Dynamic Balance in Youth Soccer Players. Exerc Sci. 2019; 28(4):373-380.

12. Blackburn JT, Norcross MF, Padua DA. Influences of hamstring stiffness and strength on anterior knee joint stability. Clinical Biomechanics. 2011; 26(3):278-283.

13. Alvares JBDAR, Rodrigues R, de Azevedo Franke R, et al. Inter-machine reliability of the Biodex and Cybex isokinetic dynamometers for knee flexor/extensor isometric, concentric and eccentric tests. Phys Ther Sport. 2015; 16(1):59-65.

14. Docherty CL, Arnold BL, Gansneder BM, Hurwitz S, Gieck J. Functional-performance deficits in volunteers with functional ankle instability. J Athl Train. 2005; 40(1):3034.

15. Plisky PJ, Gorman PP, Butler RJ, Kiesel KB, Underwood FB, Elkins B. The reliability of an instrumented device for measuring components of the star excursion balance test. N Am J Sports Phys Ther. 2009; 4(2):92-99.

16. Burkholder TJ, Fingado B, Baron S, Lieber RL. Relationship between muscle fiber types and sizes and muscle architectural properties in the mouse hindlimb. J Morphol. 1994; 221(2):177-190.

17. Kumagai K, Abe T, Brechue WF, Ryushi T, Takano S, Mizuno M. Sprint performance is related to muscle fascicle length in male 100-m sprinters. J Appl Phys. 2000; 88(3):811-816.

18. Blazevich AJ, Gill ND, Bronks R, Newton RU. Trainingspecific muscle architecture adaptation after 5-wk training in athletes. Med Sci Sports Exerc. 2003; 35(12):2013-2022.

19. Kim HD, Choi KH. The Isokinetic Knee Muscle Strength and the Anaerobic Power between Women's National Volleyball Team Players and Junior National Volleyball Team Players. KSSLS. 2007; 31:1013-1024.

20. Yoon AR, Park KS, Lee KW. Correlation Between Isokinetic Properties and Physical Fitness in University
Elite Athletes. Int J Coach Sci. 2014; 16(1):165-172.

21. Kim JH, Lee KH. Analysis of Specific Angle of Joint and Isokinetic Muscular Function on Performance Level Elite Alpine Skier`s. KSSS. 2014; 23(3):1573-1588.

22. Brughelli M, Cronin J, Nosaka K. Muscle architecture and optimum angle of the knee flexors and extensors: a comparison between cyclists and Australian Rules football players. J Strength Cond Res. 2010; 24(3):717721.

23. Singh SC, Chengappa R, Banerjee A. Evaluation of muscle strength among different sports disciplines: Relevance for improving sports performance. Med J Armed Forces India. 2002; 58(4):310-314.

24. Blazevich AJ, Jenkins D. Physical performance differences between weight-trained sprinters and weight trainers. J Sci Med Sport; 1998: 1(1):12-21.

25. Brechue WF. Structure-function Relationships that Determine Sprint Performance and Running Speed in Sport. IJASS. 2011; 23(2):313-350.

26. Methenitis SK, Zaras ND, Spengos KM, et al. Role of muscle morphology in jumping, sprinting, and throwing performance in participants with different power training duration experience. J Strength Cond Res. 2016; 30(3):807-817.

27. Blazevich AJ, Giorgi A. Effect of testosterone administration and weight training on muscle architecture. Med Sci Sports Exerc. 2001; 33(10):1688-1693.

28. Sayers MG. Influence of test distance on change of direction speed test results. J Strength Cond Res. 2015; 29(9):2412-2416.

29. Luteberget LS. Traditional versus resisted sprint training in highly-trained, female team handball players: effects on performance and muscle architecture. Ph.D. Norwegian School of Sport Sciences. 2014.

30. Kockum B, Annette ILH. Hop performance and leg muscle power in athletes: reliability of a test battery. Phys Ther Sport. 2015; 16(3):222-227.

31. Paterno MV, Schmitt LC, Ford KR, et al. Biomechanical measures during landing and postural stability predict second anterior cruciate ligament injury after anterior cruciate ligament reconstruction and return to sport. 
Am J Sports Med. 2010; 38(10):1968-1978.

32. Berdejo-del-Fresno D, Lara-Sánchez A J, González-Ravé

J M. Fitness level and body composition of elite female players in England basketball league division I. IJSES. 2012; 4(2):15-24.

33. Brumitt J, Engilis A, Mattocks A, Ellis N, Reyes J. Comparison of jump and hop test measures between
NAIA and Division III male collegiate basketball players. Athl Train Sports Health Care. 2018; 10(5):208216.

34. Sannicandro I, Piccinno A, Rosa R A, De Pascalis S. Correlation between functional asymmetry of professional soccer players and sprint. British J Sports Med. 2011; 45(4):370-371. 